\title{
Digital Transformation towards Education 4.0
}

\author{
Katyeudo K. de S. OLIVEIRA ${ }^{1}$, Ricardo A. C. de SOUZA ${ }^{1,2}$ \\ ${ }^{1}$ Graduate Program of Applied Informatics (PPGIA), Federal Rural University of Pernambuco- \\ UFRPE, Brazil \\ ${ }^{2}$ Department of Computer Science (DC), Federal Rural University of Pernambuco - UFRPE \\ Brazil \\ e-mail: karlos.1914.so@gmail.com,ricardo.souza@ufrpe.br
}

Received: April 2021

\begin{abstract}
The digital transformation of teaching processes is guided and supported by the use of technological, human, organizational and pedagogical drivers in a holistic way. Education 4.0 aims to equip students with cognitive, social, interpersonal, technical skills, among others, in the face of the needs of the Fourth Industrial Revolution and global challenges, such as mitigating the causes and effects of climate change based on people's awareness. This work presents the development and experimentation of a method, called TADEO - acronym in Portuguese language to Transformação Digital na Educação (digital transformation in education), to guide the design and application of teaching and learning experiences from groups of drivers of the digital transformation in education, aiming to achieve Education 4.0 objectives. The TADEO method was applied in the context of classes of basic subjects of elementary and higher education to increase students' understanding of climate change through the development of projects to mitigate environmental problems caused by anthropogenic action and, at the same time, exercise students the soft and hard skills required by 21 st century learning and work. The results of the evaluations of students and educators participating in the teaching and learning experiences guided by the TADEO method point to the achievement of the expected purposes.
\end{abstract}

Keywords: climate change, digital transformation, drivers, Education 4.0, TADEO method.

\section{Introduction}

According to Norton et al. (2020), digital transformation consists of a change in the organization of work motivated by emerging digital technologies and innovative business models. It involves more than the implementation of a technological solution, it is an alignment between digital technologies, human and organizational factors. According to Mahlow and Hediger (2019), digital transformation builds new skills and models through digital technologies in a deep and strategic way.

Education 4.0 and knowledge economy jobs need less and less than individuals know (concepts and theories) and more and more how people use, in an interoperable way, 
digital skills, knowledge and technologies. Education 4.0 is driving the new educational paradigm based on the application of relevant skills and based on the need to improve and requalify, unlearn and relearn (Hong \& Ma, 2020).

Among the expected results of education facing the requirements of the Fourth Industrial Revolution are: citizens' proficiency in digital technologies, seen in a more interconnected and multifaceted world, where everyday improvements based on digital technologies increasingly emerge (WEF, 2020); the school must adjust to equip students with the skills needed to create a more inclusive, cohesive and productive society (OECD, 2018b); digital skills for faculty and students to promote human, problem/ project-based learning (OECD, 2018b); and innovative pedagogies to encourage the student to take an active role in promoting and exercising the skills and attitudes necessary for the journey towards learning (Peterson et al., 2018).

For the OECD (2018b), students will have to apply their knowledge in unprecedented circumstances in a quick and continuous evolution world, but for that, they will need an extensive set of cognitive, social, emotional, practical, and physical skills. The Future of Jobs 2020 Report (WEF, 2020b) also points out that the restrictions produced by the COVID-19 pandemic and the related global economic recession accelerated the arrival of the future of work. The World Economic Forum - WEF (2016b, 2020 a) estimates that $65 \%$ of 21 st-century students will work in jobs that do not yet exist when they enter schools and they also need to be equipped with digital skills to meet the demands of emerging jobs of the Fourth Industrial Revolution. History shows that industrial revolutions influence not only production itself, but also education (Azmi et al., 2018).

Educational systems must adapt to deliver students with the skills necessary to build a more just and productive world for society. Schools must provide the learning of hard skills, such as technology design and resource management, and soft skills, such as communication, empathy and social awareness, which allow students to shape societies that are inclusive and equitable (WEF, 2020a). Such skills are essential to enable people to progress in a more complex, interconnected and rapidly changing world (OECD, 2019c).

Students who are better prepared for the future will have the ability to be agents of change, able to positively influence and understand other people's intentions and feelings and to foresee the short and long-term consequences of problems that affect society (OECD, 2018b). Therefore, according to Schleicher (2016), teachers must use digital technologies in teaching and understand the accelerated development of the fields of diverse knowledge.

Schools must qualify students for jobs and technologies that have not yet been created, as well as to solve problems that have not yet been predicted (OECD, 2018b). According to the World Economic Forum - WEF (2020a), Education 4.0 must address today's most pressing challenges, such as global climate change, ecosystem degradation and depletion of natural resources, implementing an environmental and ecological mindset of studies, involving pedagogical practices and new curricular theories, with the purpose of motivating human engagement and action in solving environmental problems. 
According to the United Nations Educational, Scientific and Cultural Organization UNESCO (2013), education has the ability to play three roles:

(1) Carry out its duty in the development of social and individual capacities and attitudes to mitigate climate change and empower people to act proactively towards the future.

(2) To develop skills, capacities and attitudes, to adapt people to the evident and imminent climatic impacts.

(3) Stimulate and reinforce the understanding of climate change, preventing people from this scenario.

With the measures adopted to contain the pandemic of COVID-19, the economic downturn was noticed and, according to UNESCO (2020), more than 1 billion students of all levels without classes, causing the greater use of digital technologies applied to the education of history. According to Manzanedo and Manning (2020), the pandemic has impacted all aspects of daily life, and has strongly affected the global economy. The provoked crisis also presents unprecedented insights into how the global climate crisis can also be managed, since there are several analogous points between the COVID-19 pandemic and what is expected from the impending global climate emergency.

In the early stage of the pandemic, it was witnessed how the blockages caused the reduction of air pollution and emissions of greenhouse gases due to the restriction of transport. This shows how the current economic activity and fossil fuels are interconnected and affect climatic conditions (Rosenbloom \& Markard, 2020).

A very challenging factor of COVID-19 is the fact that, as a result of the virus reaching a certain number of infected people, within a population, its control becomes intensely difficult. Continuous spread causes an exponential growth chain reaction. Climate change tends to play a similar role. Progressively, sudden and definitive changes can occur if temperatures rise beyond certain critical limits (Trisos et al., 2020). Still, changes in weather patterns in large proportions can trigger new and irreversible environmental processes with unpredictable outcomes (Chakra et al., 2018).

Preventive actions are essential to prevent worst-case scenarios in the climate crisis (Chakra et al., 2018) and in pandemics (Horby, 2018). For the economy, preventing or mitigating climate change is also much more efficient than when compared to adapting to it (Burke et al., 2015; Glanemann et al., 2020; Wei et al., 2020).

The theme of climate change is becoming a protagonist in school programs and curricula in several countries, however, it is still discussed superficially and as an isolated subject in the context of traditional disciplines. This theme needs to be more connected to the different knowledge of physics, mathematics, biology, science, technology, etc. (UNESCO, 2016). However, a teaching-learning strategy that is simultaneously attractive and engages students by equipping them with the skills required for 21 st century learning is also essential (UNESCO, 2019).

In this context, what is the role of Education 4.0 and how can new teaching and learning strategies contribute to the development of skills, capacities and attitudes, aiming at adapting to the consequences of climate change? Yet, at the same time, how can it stimulate students with the necessary skills for the 21 st century in the face of the challenges imposed by the Fourth Industrial Revolution? 
To present an alternative answer to these questions, this work aims to develop and experiment with a method, called TADEO - digital transformation in education (acronym in the Portuguese language to Transformação Digital na Educação), resulting from a master's thesis research. The method is applied to the digital transformation in education through the holistic use of human, technological, pedagogical, and organizational drivers in the development of teaching and learning experiences.

The TADEO method aims to contribute to the achievement of Education 4.0 purposes: to stimulate, exercise, and equip students with the skills identified as necessary for learning and working in the 21st-century; and contribute to the formation of conscientious citizens engaged in mitigating/solving relevant problems of regional and global impact, such as anthropogenic causes and adaptation to the consequences of climate change.

The article is organized into 5 sections, starting with this introduction.

Section 2 portrays the theoretical foundations that guided this work.

Then, in Section 3, the development of the TADEO Method, which consists of the main contribution of the work, is presented.

In Section 4, the application and evaluation of teaching and learning experiences developed using the TADEO Method is reported.

Finally, in Section 5, final considerations are made.

\section{Theoretical Background}

According to the Future of Jobs 2020 report (WEF, 2020b), the development and improvement of human skills and capabilities through education, learning and work are the main drivers of economic success, individual well-being and social cohesion.

In the context of education, digital transformation involves rethinking the teaching and learning processes for an audience of digital natives, considering the practical aspects of the digital transformation, through knowledge and technical skills, and being digital, through the incorporation of skill, mindset, and digital attitudes. The digital transformation towards Education 4.0 is enabled, supported and guided by technological, human, organizational and pedagogical drivers (Oliveira \& Souza, 2020a). Table 1 presents the main drivers for digital transformation in education grouped by category, found from the analysis of reports produced by international organizations that maintain permanent forums for discussion on education and economics worldwide:

- OECD - Organisation for Economic Co-operation and Development (OECD, 2017, 2018a, 2018b, 2019b),

- P21 - Partnership for 21st Century Learning (P21, 2019),

- OU - The United Kingdom Open University (Sharples et al., 2016; Ferguson et al. 2019; Kukulska-Hulme et al., 2020), and

- WEF - World Economic Forum (WEF, 2016a, 2016b, 2017, 2020a). 
Table 1

Drivers for digital transformation in education and their sources

\begin{tabular}{|c|c|c|c|c|c|}
\hline Category & Driver & OECD & $\mathrm{P} 21$ & $\mathrm{OU}$ & WEF \\
\hline \multirow{8}{*}{$\begin{array}{l}\text { Technological } \\
\text { Drivers }\end{array}$} & Cloud Computing & & & & \\
\hline & Artificial Intelligence & & & & \\
\hline & Internet of Things & & & & \\
\hline & Digital Games & & & & \\
\hline & Augmented Reality & & & & \\
\hline & $5 \mathrm{G}$ Networks & & & & \\
\hline & Social Networks & & & & \\
\hline & Educational Software & & & & \\
\hline \multirow{10}{*}{$\begin{array}{l}\text { Organizational } \\
\text { Drivers }\end{array}$} & Develop Education 4.0 Strategy & & & & \\
\hline & Develop, Update an Adapt Curriculum & & & & \\
\hline & Using Digital Technologies for Communication & & & & \\
\hline & Promotion of Learning to Learn Skills & & & & \\
\hline & $\begin{array}{l}\text { Improving the Educational Experience Using Digital } \\
\text { Technologies }\end{array}$ & & & & \\
\hline & Encourage Interdisciplinary Study & & & & \\
\hline & Working with Innovative Pedagogies & & & & \\
\hline & Using Hybrid Teaching Methods & & & & \\
\hline & Assessment and Feedback of Practices Adopted & & & & \\
\hline & Autonomy for teachers to innovate & & & & \\
\hline \multirow{8}{*}{$\begin{array}{l}\text { Digital Teaching } \\
\text { Competence }\end{array}$} & Teach Learn to Learn & & & & \\
\hline & Provide Constant Feedback & & & & \\
\hline & Integration of Digital Technologies for Universal Education & & & & \\
\hline & Know which technology to use according to need & & & & \\
\hline & Teamwork and Planning & & & & \\
\hline & $\begin{array}{l}\text { Use of Digital Technologies for personal and collective } \\
\text { teaching and learning }\end{array}$ & & & & \\
\hline & Using Innovative Pedagogical Approaches & & & & \\
\hline & Using Innovative Assessment Methods & & & & \\
\hline \multirow{14}{*}{$\begin{array}{l}\text { Soft Skill } \\
\text { Student }\end{array}$} & Adaptability & & & & \\
\hline & Learn to learn & & & & \\
\hline & Communication & & & & \\
\hline & Social and Cultural Awareness & & & & \\
\hline & Creativity & & & & \\
\hline & Curiosity & & & & \\
\hline & Empathy & & & & \\
\hline & Initiative & & & & \\
\hline & Leadership & & & & \\
\hline & Critical Thinking and Analytical Thinking & & & & \\
\hline & Persistence & & & & \\
\hline & Responsibility & & & & \\
\hline & Problem solving & & & & \\
\hline & Teamwork & & & & \\
\hline
\end{tabular}

Continued on next page 
Table 1 - continued from previous page

\begin{tabular}{|c|c|c|c|c|c|}
\hline Category & Driver & OECD & $\mathrm{P} 21$ & $\mathrm{OU}$ & WEF \\
\hline \multirow{9}{*}{$\begin{array}{l}\text { Hard Skill } \\
\text { Student }\end{array}$} & Digital Technologies Design & & & & \\
\hline & People management & & & & \\
\hline & Quality management & & & & \\
\hline & Technological resource management & & & & \\
\hline & Risk management & & & & \\
\hline & Time management & & & & \\
\hline & Financial management & & & & \\
\hline & Computational Thinking & & & & \\
\hline & Creative Problem Solving & & & & \\
\hline \multirow[t]{6}{*}{ Pedagogy } & Innovation Approaches & & & & \\
\hline & Problem-Based Learning & & & & \\
\hline & Project-Based Learning & & & & \\
\hline & Playful Learning & & & & \\
\hline & Action Oriented Learning & & & & \\
\hline & Blended Learning & & & & \\
\hline
\end{tabular}

A digital transformation towards Education 4.0 must deal holistically: use of digital technologies, considering the specificities of students; adoption of organizational processes and practices in alignment with new social and work relationships; equip teachers with digital skills (do and be) to deal with native digital students; equip students with the technical, cognitive, social and emotional skills necessary for 21 st century learning and work; and the adoption of innovative pedagogies focused on the transfer and acquisition of knowledge on demand to solve a problem or perform a task.

Among the main technological drivers of digital transformation in education are educational software. Barbosa and Souza (2021) present a method based on drivers and innovation indicators to guide the development and evaluation of educational software. Such drivers and indicators, categorized in technological and pedagogical, are associated with the skills and competences necessary for students to learn the 21 st century.

The combination of hard skills and soft skills is essential to achieve leadership and professional success. Rao (2018) presents an approach to help equip students with hard skills and soft skills, based on experimental learning guided by active pedagogies.

The digital transformation in education must consider the training of teachers and the organization of educational institutions. According to Goh and Abdul-Wahab (2020), teachers represent the front line in the training of students, and they need to be trained in the use of new teaching methodologies for digital students in a digitalized world. Educational institutions, on the other hand, need to move away from the traditional way of transmitting knowledge and providing autonomy to educators, to experiment with new pedagogies for students, to establish their own learning pace, both with the help of technology.

Education 4.0 seeks to equip students with the skills necessary for 21 st-century learning and work and prepare them to act on relevant social challenges as the UN Sustainable Development Goals (SGD) (UN, 2015). Among the main strategies to 
achieve the SDG is the green economy, which encompasses the low-carbon economy and green jobs. The green economy consists of economic activities related to the production, distribution, and consumption of goods and services that result in the evolution of social well-being. The green economy aims not to expose future generations to high environmental risks (UNEP 2011, 2012). The purposes of the green economy are to mitigate carbon emissions into the atmosphere, adapt humans to extreme weather events, eradicate poverty, and generate jobs for local communities. According to Dudin et al. (2016), the education systems serve as a strategic basis for reaching green economy purposes.

With growing concern and awareness of environmental issues, there is a greater need to expand educational outreach about the consequences of the rapidly changing climate, depletion of natural resources, and global challenges related to food security and human health. These challenges are associated with opportunities for a wide range of ocean-related industries, fostering the so-called blue economy (Spinrad, 2021).The blue economy also requires innovative and interdisciplinary educational programs dependent on greater integration of technical, scientific, and management skills (Hotaling, 2021).

Mitigating the anthropogenic causes of climate change is another major challenge for this generation. According to UNESCO (2013), education is an essential factor to deal with various pressing issues in society, such as, for example, dealing with the causes and impacts of climate change, stimulating attitudes and habits to promote more ecologically sustainable lifestyles.

Among the strategies adopted by several countries to increase awareness and knowledge about climate change is the introduction of Environmental Education in school curricula. Environmental Education involves approaches and tools that build and ground attitudes, awareness, knowledge and skills related to the environment that enable people to make decisions and act in a more environmentally responsible way (Monroe \& Krasny, 2015).

According to Assadourian (2010), a portion of educational organizations do not meet the pretensions of the environmental aspect, which demands ideas such as collaboration, solidarity, good use of natural resources and concrete citizen training. An educational organization, by emphasizing only technological training, placing human subjects of politics, ethics, environment and sustainable development in the background, is oriented towards forming consumerist societies. Thus, to enable the link between the environmental aspect and the development of relevant skills, Environmental Education can be used in the school environment.

According to Monroe and Krasny (2015) and Ardoin et al. (2020), Environmental Education represents more than a unidirectional transfer of information, instead it is a set of tools that develops and improves environmental attitudes, values and knowledge, as well as builds skills that enable individuals and communities to undertake environmental actions collaboratively.

Environmental Education has been discussed as a state policy for several decades. In 1972, the UN (UNESCO, 1972) held the first World Conference on Environment and Development, the first in a series of conferences aimed at discussing environmen- 
tal problems and articulating the economy with the conscious handling of natural resources. In 1992, with the realization of RIO-92 (UNESCO, 1992), the term sustainable development gained greater relevance, consolidating itself as a tool to combat environmental problems.

Sustainable development inextricably involves the social, environmental, and economic dimensions (Loiseau et al. 2016). This work presents a method to guide the development of teaching and learning experiences aligned with Education 4.0. The proposed method is concerned with fostering the skills necessary for 21 st-century learning and working and solving emerging social problems such as mitigating the anthropogenic causes of climate change. The proposed method thus considers all dimensions of sustainable development.

Therefore, it is necessary to apply drivers of digital transformation in education, considering: the use of technology, considering the online teaching modality, the high interest on the part of digital native students, and autonomy in learning at any time and anywhere, etc.; the application of innovative pedagogies encouraging students to learn by doing, acquiring and applying knowledge and skills in building solutions to problems experienced in everyday life; the exercise of soft skills and hard skills by students, in order to equip them with the being, knowledge and doing, necessary to make them engaged citizens and competent workers in the work of the fourth industrial revolution; the development of digital skills by teachers, for the appropriate use of technology considering the specificities of students and the most efficient digital means for the transfer of knowledge; and, finally, the opening and adaptation of the educational institution for the digital transformation in education.

Thus, in order to guide the application of drivers of digital transformation in education in teaching and learning experiences, the TADEO Method is presented below, as well as the application of the method in the context of Environmental Education.

\section{TADEO Method}

The TADEO Method aims to guide the development of teaching and learning experiences by educators considering the multidisciplinary nature of the causes and effects of climate change and encourage the exercise of skills necessary for Education 4.0. The teaching and learning experiences sought to increase students' understanding and awareness of the anthropogenic causes of climate change through the design and prototyping of solutions that lead to more environmentally sustainable human behavior.

\subsection{Conceptual Model of the TADEO Method}

Fig. 1 presents the Conceptual Model that provides an overview of the concepts, approaches and associations between them, which guided the development of the TADEO method. The TADEO method is based on the drivers of digital transformation in education, identified from the analysis of reports produced by international organi- 


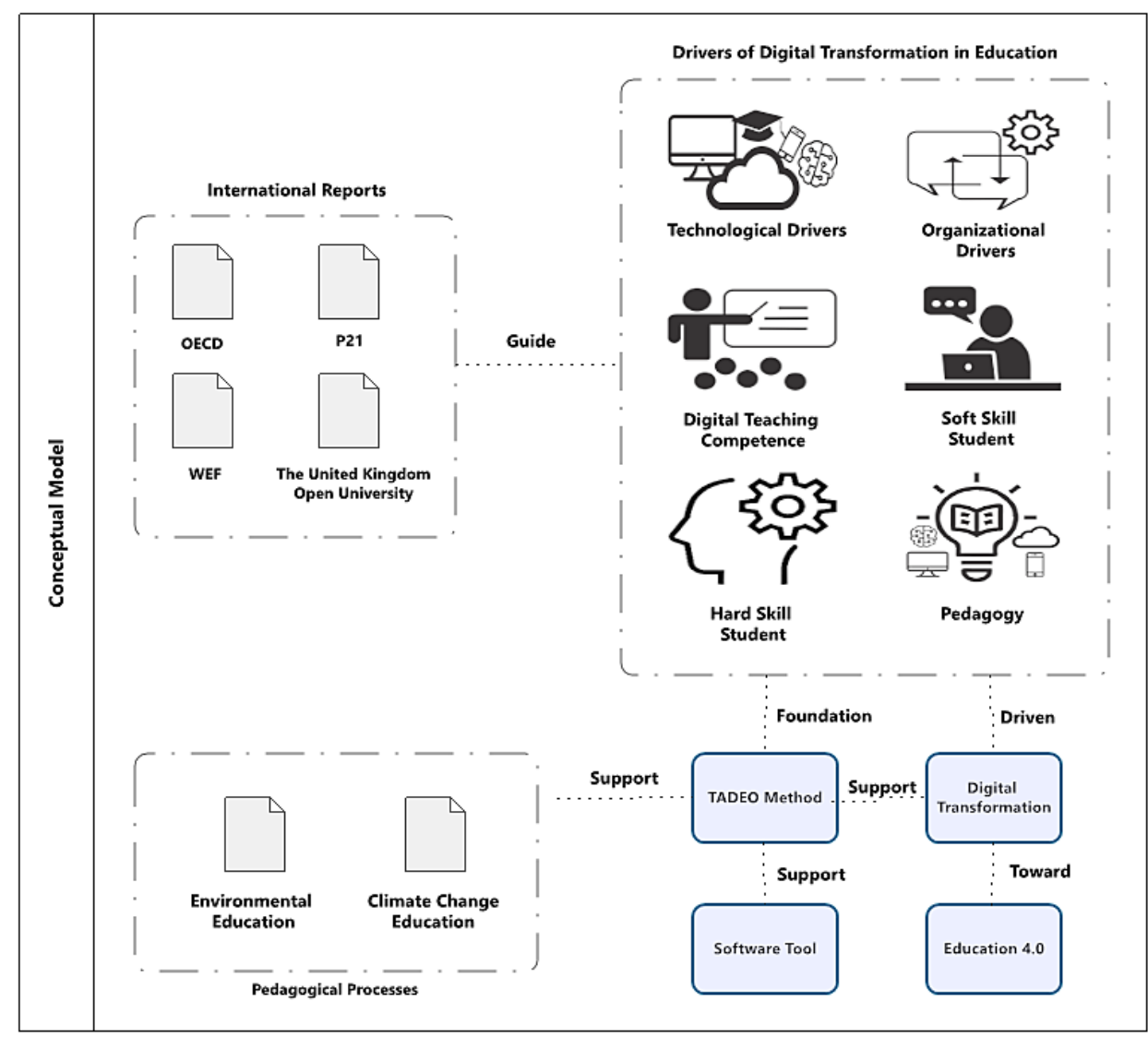

Fig. 1. Conceptual Model of the TADEO Method.

zations, such as, OECD and WEF. The TADEO method is aligned with pedagogical processes concerned with the insertion of the theme of climate change in education and technologically supported by a software tool, based on the WEB, developed for this purpose.

Drivers support, enable and direct digital transformation initiatives in education. Such drivers are grouped in the categories Technological, Organizational, Digital teaching competence, Soft skill student, Hard skill student and Pedagogy. The drivers of digital transformation in education were identified from the analysis of reports from international organizations that discuss education worldwide, as shown in Table 1.

The TADEO Method supports Environmental Education and other pedagogical approaches such as Climate Change Education (UNESCO, 2013). From a systematic mapping study (Oliveira \& Souza, 2020b), it was possible to identify the educational strategies most used and cited for understanding and awareness of the causes and impacts of climate change: Climate Change Education and Environmental Education. En- 
vironmental Education aims to build citizens who can act to protect and improve the environment, consisting of an interdisciplinary and dynamic form of education, focused on the study of the environment and ecological systems (Anderson, 2012). Climate Change Education is a powerful tool to develop responses and help students understand the causes and consequences of climate change, preparing them to live with the impacts and enable them to take appropriate actions to adopt more sustainable lifestyles (UNESCO, 2013).

The drivers support the TADEO method and guide the digital transformation in education. According to the OECD (2019a), digital transformation affects the whole of society and to accompany it, a combination of strong cognitive skills is required, along with behavioral and interpersonal skills in problem solving, communication and creativity. The digital transformation in education involves rethinking the teaching and learning processes for "digital native" students, considering the aspects of making digital, through technical knowledge and skills, and being digital, through the incorporation of digital skills, mentality and attitudes.

The TADEO method supports the digital transformation towards Education 4.0. According to the World Economic Forum (WEF, 2020a), Education 4.0 should emphasize how knowledge is passed on to students, rather than what content is taught. Education 4.0 equips students with the technical, cognitive, social and emotional skills necessary for learning in the 21 st century, and with digital skills for the future of work (WEF, 2020a). The digital transformation in education should not be seen as a project, but as a permanent way of working, thinking and acting, seeking to explore digital technologies to improve educational experiences (Oliveira \& Souza, 2020a).

The TADEO method aims to support the digital transformation towards Education 4.0. Education 4.0 is concerned not only with what content is teaching. This new education model emphasizes how knowledge is transferred to the students. In addition, Education 4.0 aims to equip students with technical, cognitive, social, and emotional skills needed for learning in the 21 st-century and with digital competencies for the work of the future (WEF, 2020a). Digital transformation in education should not be seen as a project but as a permanent way of working. It is necessary to explore digital technologies to improve educational experiences (Oliveira \& Souza, 2020a).

Finally, the TADEO method is technologically supported by a web-based software tool developed for this purpose, through which teaching and learning experiences can be designed by specifying the purposes of each of the drivers of digital transformation in education, according to what is needed for each educational experience.

\subsection{Technological Support Software Tool to the TADEO Method}

The software tool of technological support to the TADEO method, available at the electronic address http: //tadeo.com.br, can be used by teachers to assist the design of teaching and learning experiences from the use of a set of drivers to digital transformation in education. 
The web-based tool offers the following main functionalities: interactive panel with the drivers of digital transformation in education; construction of teaching plans, through the drivers selection, the purpose of teaching, the duration of activities, the necessary materials and the evaluation method that will be used; digital repository of work products produced by students in teaching and learning experiences; and dashboards with the result of self-assessments and peer reviews carried out by students.

\section{Application of the TADEO Method}

The method application consisted of the development of teaching and learning experiences, in real classrooms, aiming to contribute to the achievement of the purposes of Education 4.0, more specifically in fostering in students: some of the skills pointed out as necessary for learning and work 21 st-century; raise students' awareness and knowledge about the causes and effects of climate change by developing solutions to climate challenges; and foster the teaching and learning of climate change integrated into the traditional basic disciplines program. Fig. 2 shows the basic flow used to structure teaching and learning experiences developed through TADEO method.

The actors involved were: author of the work, researcher proposing the method; educator, teacher of the discipline; and students enrolled in classes. The flow started with the Planning stage, through which the author of the work and the educator designed the teaching and learning experience from the use of context-specific drivers of digital transformation in education.

The flow continued with the Execution stage of the teaching and learning experience, in which iterations (sprints) were carried out for specific purposes: Discovering Challenge, to frame an educational challenge; Deeping Understand, to uncover insights into context; Generating and Refining Ideas, to unlock creative power to build and combine ideas for satisfy insights; and Prototyping Ideas, to build solution prototype quickly. The design of the sprints was based on pedagogical drivers, more specifically approaches to innovation and problem-based learning. A sprint, a term derived from the SCRUM agile method (Schwaber, 2004; Parsons \& Maccallum, 2019), consists of planning, execution and status report mini-cycles (iterations) of the tasks performed. Sprints (iterations) allow structuring the learning process through shorts and continuous deliveries. Iterations allow to mitigate risks and reduce the complexity of projects in incremental parts of reduced scope. The agile paradigm can be used in education to help students perform complex tasks (Vogelzang et al., 2020) and improve the knowledge use in a disciplined, critical, and creative way, promoting the coexistence of heterogeneous human groups developing the ability to think, live and act autonomously (Jurado-Navas and Munoz-Luna, 2017).

Tasks to achieve the sprint's goals were carried out aided by tools, practices, and drivers for the digital transformation in education. Student groups performed the tasks with follow-up and supervision by the educator. At the end of each sprint, each student did a performance self-assessment and also he/she did a performance assessment of other students of their group. 


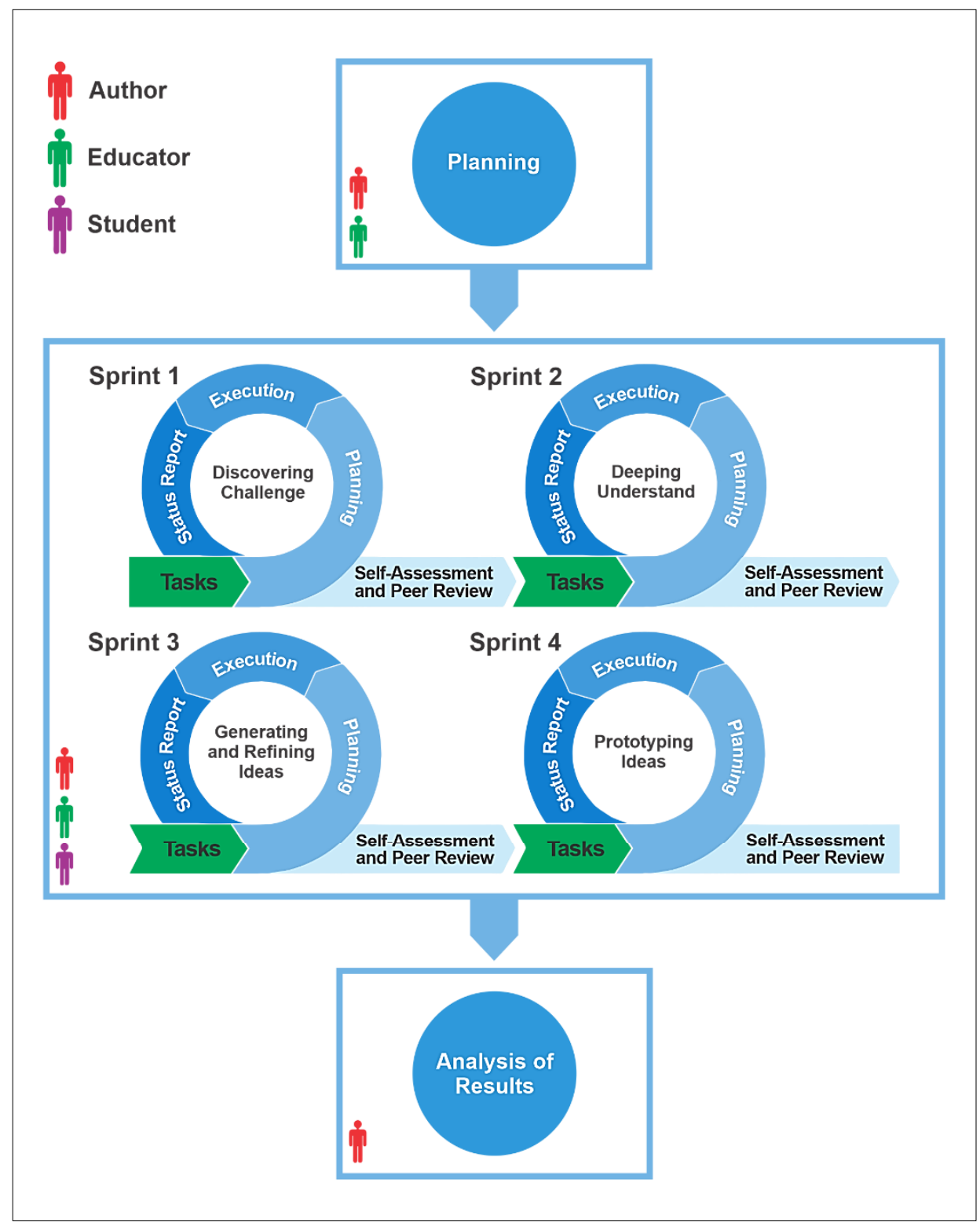

Fig. 2. Execution Flow of Teaching and Learning Experiences.

The flow ended with the stage of Analysis of the Results of the teaching and learning experiences by the author of the work. The feedback of the students and educators involved were analyzed and structured in comparative charts. 


\subsection{Planning Stage of Teaching and Learning Experiences}

The TADEO method was used to guide the design of two teaching and learning experiences based on the flow described in Fig. 2. The planning stage consisted in the selection of drivers for the digital transformation in education, considering the level of teaching, the specifics and students' realities, and the digital skills of educators. This stage was carried out by the educators with the assistance of the author of the work. Due to the physical isolation measures against the pandemic of COVID-19, teaching and learning experiences were applied in the form of remote teaching. Altogether, 29 students and 2 teachers from different educational institutions participated in the two teaching and learning experiences (Experience 1 and Experience 2).

Experiment 1, which took place between August 26 and September 24, 2020, included the participation of 16 students from the 9th grade of elementary school, aged between 14 and 16 years old, with 7 female students and 9 male students. The participating educator was a teacher with a Specialist education level, who works in the teaching of History and Geography, with 6 years of teaching experience.

Experiment 2, which took place between August 26 and December 9, 2020, involved the participation of 13 undergraduate students in Systems Analysis and Development at a university center, with the age group between 20 and 29 years old, with 3 female students and 10 male students. The participating educator was a teacher with a Master's degree in Computer Science, with 5 years of teaching experience.

To structure both teaching and learning experiences, pedagogical drivers were used, the Human-Centered Design (HCD) process (IDEO, 2015), the Problem-Based Learning (PBL) approach (Hmelo-Silver, 2004) and the management paradigm agile (Bruegge et al., 2009). Experiments 1 and 2 were structured in four iterations (sprints) with a specific purpose:

(1) Discovering the challenge, to find a key question to guide the development of the project.

(2) Deepening the understanding, for immersion in the context or problem in search of insights (opportunities).

(3) Generating and refining ideas, for co-creating proposals for solving the challenge from the exploration of one or more insights.

(4) Prototyping ideas, to prototyping the idea of solving the most promising challenge.

The life cycle of each sprint consisted of three stages:

(1) Planning, for the team to analyze tasks and define responsibilities.

(2) Execution, for tasks to be performed by the team.

(3) Status report, for presentation of the task results by the team to the educator.

The tasks of each sprint were defined in accordance with the purpose of the respective sprint and are conceptually grouped in four ways:

(1) Empathy, putting oneself in the other's shoes, identifying pains / problems and proposing solutions from the perspective of the people. 
(2) Creativity, understanding the world from different perspectives, looking for many different alternatives and coming up with innovative solutions.

(3) Experimentation, materialize ideas to test them and keep the focus on the project's viability.

(4) Learning, learning from failure and the feedback obtained.

The tasks of Sprint 1 consisted of: Raising collective experiences, asking and knowing the level of understanding about climate change; Analyze critically various explanations of human and natural factors that determine climate change; and Think and discuss recent evidence on climate change. The tasks of Sprint 2 consisted of: Reflecting on the impact of climate change on people's lives; Engage with people's feelings about climate change and work to convert those feelings into feelings of purpose and commitment to transformative action; and Challenge their own perceptions and understandings by introducing other perceptions and understandings about climate change. The tasks of Sprint 3 consisted of: Analyzing the extent to which climate change interferes with the imagination and the vision of the personal and collective future; Investigate the interaction between the consequences and, thus, encourage critical thinking about the impacts of climate change; Identify and systematize questions about climate change; and Reflect on the planning and implementation of a change initiative in relation to mitigation, risk reduction and adaptation to climate change. Finally, the tasks of Sprint 4 consisted of: Analyzing and presenting what was seen and learned; Allow students to share experiences, knowledge and personal feelings regarding climate change; Reflect lessons learned on climate change; and Enable the exchange of experiences and personal knowledge on climate change.

Each sprint was intended to help students understand the causes and consequences of climate change, in order to prepare them to live with the impacts and enable them to take the appropriate actions to adopt more sustainable lifestyles, as well as exercising technical, social, interpersonal and cognitive skills in them.

\subsection{Execution Stage of Teaching and Learning Experiences}

Initially, each educator explained the teaching and learning experience, structured by means of timeboxing sprints with a well-defined scope for carrying out tasks and delivering the results at the end. Experiment 1 was composed of four teams of four students, while Experiment 2 had three teams, two teams with five students and one team with three students. The composition of the teams was delegated by the educators to the students themselves.

Subsequently, each educator explained what was expected for each sprint, as well as the ultimate goal of the teaching and learning experience. In addition, each educator performed a basic explanation of the tools, practices and drivers needed to perform the sprint tasks, in order to ensure that all students would have the necessary fluency, for example, in the handling of technological drivers, since not everyone could have the habit or sufficient knowledge about the chosen technology. 
In the status report stage of the sprints, each educator evaluated the tasks performed and defined the deliveries as accepted or in need of correction. At the end of each sprint, by means of an electronic questionnaire, each student carried out a self-assessment and assessed the other members of his team on individual and collective performance, respectively. At the end of the experiments, the educators also provided feedback by filling out an electronic form.

To exemplify the execution of the teaching and learning experiences carried out, a synthesis of Experiment 2 carried out in the context of the discipline of Technology, Science and Society of an undergraduate course will be presented. Experiment 2 sought to address advances in the computing industry and the impacts on society and the environment caused by factors such as energy consumption and inappropriate disposal of equipment, as well as sustainable alternatives such as green computing.

The execution of the sprints consisted of performing tasks assisted by practices and tools of the HCD process. In Sprint 1 - Discovering Challenge, groups of students were instructed to use: Problem Map, to visually capture the various interconnected problems and linked to a given central or main problem; and Design Challenge, to summarize the problem/challenge to guide the project in one issue. In Sprint 2 - Deepening Understanding, groups of students were instructed to use: Personas, to identify the archetypes interested in solving the challenge; Stakeholders Map, to identify those directly or indirectly affected by the problem; and Mind Map, to visually organize discoveries and understandings at the end of the sprint. In Sprint 3 - Generating and Refining Ideas, groups of students were instructed to use: Insight Cards, to structure the identification of opportunities related to the challenge; How We Might? (HWM), to structure in sentences different ways to explore the insights (opportunities) identified; and Storyboard, to visually sketch and refine different ideas for responding to formulated HWM sentences. Finally, at Sprint 4 - Prototyping Ideas, groups of students were instructed to use: Prototype, to materialize the ideas for solving the challenge; User Journey, to structure the main moments of the knowledge experience (before), use (during) and dissemination/ recommendation (after) of the developed solution; and Pitch, to present the results of the project, with an emphasis on delivering value from the developed solution. Deliveries of the sprints from Experiment 1 and Experiment 2 are available for consultation at http://tadeo.com.br/experiencias.php.

At the end of Experiment 2, student groups delivered prototypes based on digital technology to meet the respective challenge that guided the development of the project. Team 1 produced a prototype of a software application to address the problem of improper disposal of electronic waste, considering information on the impact on the environment and guidance on appropriate forms of disposal, reuse, recycling and circular economy. Team 2 produced a prototype of a software application with the purpose of fostering a network of interested parties in donations and sales of used electronic equipment. Team 3 produced a prototype of a software application with the purpose of acting as an intermediation tool between public and private organizations, waste collection workers and the population in general, for the dissemination of collection points, disposable electronic equipment, training of collectors, generation of income, and social empowerment. 
The following paragraphs describe the drivers of digital transformation in education used in Experiment 2, grouped by category, as well as their relationship with the tasks performed in the sprints.

\section{Technological Drivers}

- Social Networks: the WhatsApp application (whatsapp.com) was used for synchronous communication and feedback between students and the educator during the project. The pitch of the solution was shared on YouTube (youtube.com).

- Cloud Computing: the virtual meetings between the students and the educator were mediated by the Canvas environment (instructure.com/canvas/pt-br). Google Drive (google.com/intl/pt/drive) was used to enable students to store and share work products. To manage the tasks, the Trello tool (trello.com/ pt-BR) was used. The Personapp application (personapp.io) was used to create the Personas for the project. The Coggle tool (coggle.it) was used for the elaboration of the Mind Map. The Storyboardthat tool (storyboardthat.com) was used to build the Storyboard. All the tools used are hosted on cloud computing.

\section{Organizational Drivers}

- Develop Education 4.0 Strategy: consisted of organizational adaptation according to the social and technological restrictions of the educational institution, proposing viable opportunities and solutions so that it was possible to align the practices of the experience with the educational practices.

- Develop, Update an Adapt Curriculum: educational practices were analyzed and updated, adapting to the institution's schedules. Based on the assumption that an extracurricular course on climate change is not necessary, the curriculum was adapted to cover relevant issues in the disciplines proposed in the experience.

- Improving the Educational Experience Using Digital Technologies: use of digital technologies, aiming to increase student interest and enable a better educational experience, expanding the possibility of acquiring knowledge through a context close to reality.

\section{Digital Teaching Competence}

- Provide Constant Feedback: through the activity management tool Trello, the educator was able to view and check the status of tasks (to do, doing and ready), providing continuous feedback on their execution. The WhatsApp tool was also used in order to provide real-time feedback and suggestions to the teams, thus making it possible to mitigate the risks of teams not performing tasks.

- Know which technology to use according to need: during the execution of the sprints, the educator managed the use of technological drivers, confronting the usefulness and adequacy of the available resources to the learning strategies for the students.

- Using Innovative Assessment Methods: use of student learning assessments through methods such as storyboard, self-assessment, peer review, and delivery of work products. 


\section{Soft Skill Student}

- Communication: during the explanation of which technology and how to use it, the educator provided space for clarification and suggestions by the students. Through the Design Challenge tool, the group of students had the opportunity to communicate the problem to be solved. Through the Insights Cards and How We Might? tools, internal communication between students in the group was stimulated, exploring the creative potential and encouraging them to freely express their ideas. Using the tools Problem Map, Personas, Mind Map, Stakeholders Map, Prototype, User Journey and Storyboard, visual communication was exercised through graphic and narrative elements. Through Pitch, lean and objective communication of the results achieved was stimulated.

- Social and Cultural Awareness: it was possible to articulate the problem that the team was trying to solve, taking into account the context and the social and cultural restrictions that climate change causes and, thus, perceive the society around them and assist in the formation of behavior and worldview.

- Creativity: stimulating creativity for proposing solutions. During the execution of the sprints, the students had autonomy for decision making, problem solving and the ability to innovate.

- Empathy: through the Problem Map, students were encouraged to think about social, political, environmental, economic issues, among others, putting themselves in other people's shoes, trying to understand them, trying to find out what was motivating or causing the problem. The formulation of the Design Challenge allowed students to synthesize a problem or a social demand relating to climate change, considering the point of view of all team members to understand people's needs and feelings for the creation of a more sustainable society. Using Personas, Stakeholder Map, Insight Cards and How We Might? tools, it was possible to understand the needs, experiences, behaviors and goals of people involved with the team idea, helping to recognize that people have different needs and expectations and also to identify with the user. Through the User Journey tool, students synthesized the main moments when the user would try the solution, in questions of how he would know the solution, when he would decide to use it for the first time and how the solution could impact his life, that is, the students had to try to understand the others around them, allowing themselves to feel what they felt and putting themselves in the same situation.

- Critical Thinking and Analytical Thinking: through sprints containing articulated tasks, students were encouraged to use the critical and analytical thinking process to organize information and ideas, make decisions, refine and acquire knowledge for the development of solutions focused on people.

- Responsibility: the teams organized and managed tasks, technologies, schedules and people to make it possible to achieve the expected results in each sprint.

- Problem solving: students were challenged to propose solutions based on digital technologies to mitigate the anthropic causes of climate change.

- Teamwork: students were distributed in teams to develop all sprints in a collective and collaborative way. 


\section{Hard Skill Student}

- Digital technologies design: at the end of Experiment 2, students developed a solution based on digital technology to reduce environmental impacts according to the concepts presented in the discipline.

- People management: each student had the opportunity to lead their peers in carrying out the proposed tasks. To assess the students' behavior and perspective, self-assessment and peer assessment was carried out at the end of each sprint.

- Technological resource management: for each task, the professor suggested some technological tools for the execution. However, the teams had to analyze, select and use the technological resources, according to the need of the task and the availability (difficulty of access, lack of fluency in the use, etc.) of each team member.

- Time management: the teams exercised self-management to deliver results at the end of each timeboxing sprint.

- Computational Thinking: to develop solutions based on digital technologies, students exercised elementary concepts such as decomposition and abstraction when performing sprint tasks.

\section{Pedagogy}

- Innovation Approaches: use of the stages of the Human Centered Design (HCD) process as a basis for structuring the sprints, as well as HCD tools and practices to assist in the execution of tasks.

- Action Oriented Learning: students were encouraged to reflect on learning and achieving results at the end of each sprint, and what they would do differently for the next sprint.

- Blended Learning: use of offline and online educational techniques, allowing the student to learn alone, without the presence of the teacher and, on other occasions, to have moments of facilitating learning with the synchronous guidance of the teacher.

\subsection{Results Analysis Stage}

The results presented below refer to the average of self-assessment and peer assessment performed by students at the end of the four sprints on the soft skill and hard skill students stimulated in Experiment 2. The objective was to evaluate some of the cognitive, social, interpersonal skills and techniques needed by students according to the purposes of Education 4.0. The individual adoption of a driver can bring benefits and challenges but the combination of them toward a true digital transformation in education. To this end, the students answered an electronic form with questions whose answer alternatives were based on the Likert scale from 1 - "strongly disagree" to 5 - "strongly agree".

Fig. 3 shows the percentages of the self-assessment of students who participated in Experiment 2. From the visualization of the graph, it is possible to verify that all skills (soft skills and hard skills) stimulated in the Experience were evaluated positively in the students' self-assessment. 


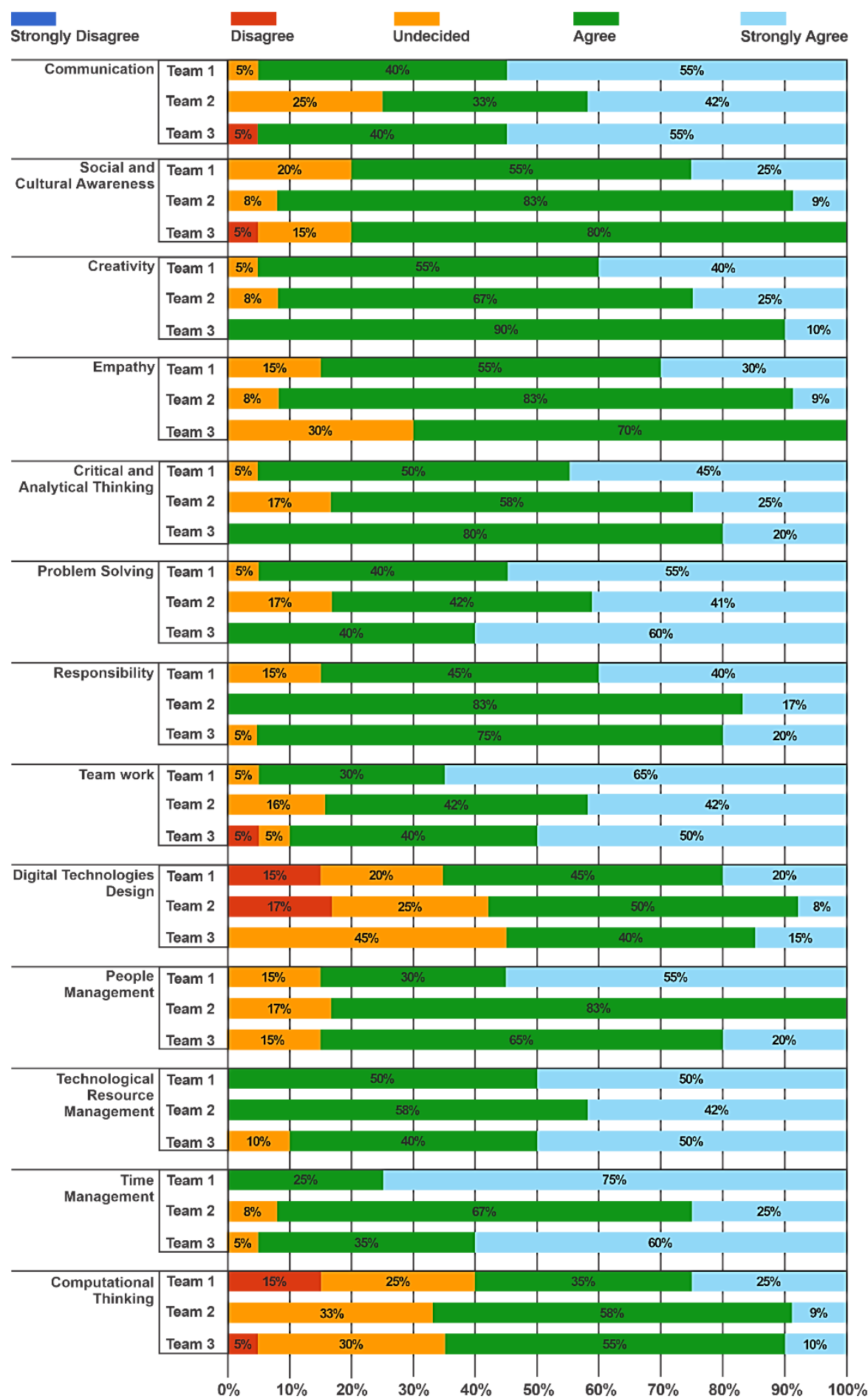

Fig. 3. Soft Skills and Hard Skills self-assessment of Experience 2. 


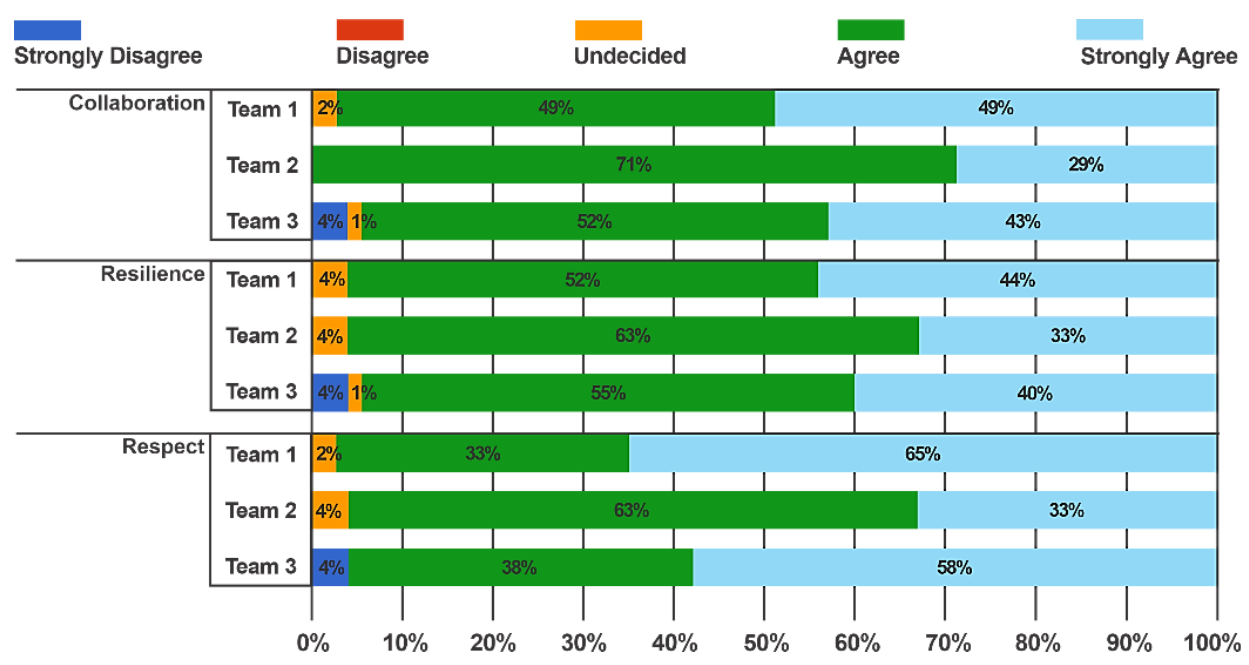

Fig. 4. Peer Review Experience 2.

Fig. 4 shows the percentage of peer evaluation of Experiment 2. When analyzing the graphs, it is noted that, in the students' perception, there was collaboration between the team members to obtain the results achieved in the sprints. This allowed each student to develop their own learning processes, but in collaboration with other students.

In the electronic peer review form, there was an open question in which students could optionally provide feedback at the end of each sprint. For this analysis, students will be identified by a number, for example, Est 1 - Student 1. This analysis consisted of discussing the results of qualitative evaluations of students on teaching and learning experiences, considering only Experience 2. The following statements have been translated into English (own translation), however, keeping them in their entirety.

When analyzing the students' responses, it was possible to observe that communication and teamwork skills were present in several reports, among them: "Unlike the other disciplines that are being online, in this one I am communicating better with the team and with the teacher." (Est1). The World Economic Forum (WEF, 2020a) emphasizes that in an increasingly interconnected world, communication and teamwork skills will become increasingly essential in the formation of future professionals defending more inclusive economies.

Other important skills for 21 st century learning, problem solving, critical and analytical thinking and social and cultural awareness (OECD, 2018b), were also noted: "Social causes should be addressed more in other disciplines as well. I think it would be possible to address several relevant topics, and not just technical content in the disciplines." (Est3). The development of critical thinking skills in learning can be done using the appropriate learning methods (Noviyanti et al., 2019). In addition to fundamental literacy skills, people now need skills such as critical and analytical thinking and problem solving (OECD, 2019a). 
An important factor worth mentioning and that was the subject of this work, climate change, was also highlighted: "It is very interesting and important to unite education with the debate on sustainability and climate change. I realized that it is a topic that can be addressed in several disciplines." (Est12); "Very different from everything I've done in other disciplines. I liked the way of running the sprints and seeing how each execution complemented the other. Even more interesting was to note how it is possible to bring together the understanding of climate change and the content of the discipline, since they were contents that I did not imagine could be seen at the same time." (Est5).

In a coexistence scenario caused by COVID-19, which strongly impacted the students' daily lives, it was possible to observe a relevant contribution from the experiences: "It was something new, however, interesting because everything depended on teamwork. So, how to organize, delegate tasks and control time was of utmost importance." (Est5); "The easiness to control the time is the differential of this experience. All tasks are linked to each other. Very good to have an idea of what is going to be done." (Est8).

It is worth noting that the purpose of these experiences is their ability to be replicated in other educational contexts and environments, where the students also emphasized: "It was an important experience to help me better control my time, organize myself better. I used the techniques learned from that experience to organize the other disciplines." (Est13); "This experience is important to show how the teaching process can be different. I believe that it is important to do the teaching in an interdisciplinary way most of the time as a team." (Est1); "One of the interesting points that I am noticing is how the requested tasks are connecting and pulling the others. I liked this format of not having the contents disconnected and without a defined logic." (Est2).

At the end of the project, an interview was conducted with the educators so that it was possible to characterize their vision regarding the execution of teaching and learning experiences. For this analysis, the educator will be identified according to the experience he participated in, where the teacher of Experience 2 will be 'TeaExp2'.

When asked how the proposed experience contributed to raising students' awareness and knowledge about the causes and effects of climate change, TeaExp2 pointed out that "linking theoretical knowledge with analytical skills about the environment and society provides more training robust for students".

According to Schleicher (2016), teachers need to use digital technologies in teaching and understand the accelerated development of fields of knowledge. Thus, the teacher was asked what chance he would use or recommend the experience in other projects, subjects or classes. To this question, TeaExp2 replied that "yes, I would definitely use or recommend it. The proposed model was widely accepted by the students".

Finally, the teacher was asked to describe suggestions, criticisms or observations in general about the experience of digital transformation in environmental education. TeaExp2 pointed out that "the methodology can be applied to several disciplines, taking into account the contextual adaptations of each discipline, so that the student constantly feels the relationship between the content and the applied methodology".

The results of the quantitative and qualitative analysis of Experiment 2 suggest that the combination of technological, organizational, human and pedagogical drivers, when 
used holistically for the digital transformation in education, can help achieve the purposes of Education 4.0 with regard to equip students with technical, social, cognitive and interpersonal skills and in promoting the resolution of relevant problems, such as mitigating the anthropic causes of climate change.

\section{Conclusion}

The TADEO Method can contribute to the knowledge area of innovation in education. It presents a differentiated teaching and learning approach focused on how knowledge is transferred to students, based on fostering the skills and competencies necessary for 21st-century learning (Ananiadou \& Claro, 2009; Binkley et al., 2012), rather than focusing on what knowledge is taught. From a technical point of view, one of the contributions is the possibility of using the TADEO method in the knowledge and awareness of students about the causes and effects of climate change in a stronger connection with basic subjects, as recommended by UNESCO (2013). The TADEO method is based on human, technologic, pedagogic, and organizational drivers used in a holistic way.

The research method that guided the development and application of the TADEO Method consisted of the following activities: specification of drivers for digital transformation in education, grouped into the technological, organizational, digital teaching competence, students' soft and hard skills, and pedagogy; specification of a conceptual model; implementation of a software tool for technological support; planning and execution of teaching and learning experiences guided by the method; and analysis of the results obtained.

The TADEO Method aims to contribute to the achievement of Education 4.0 purposes - to equip students with the technical, social, cognitive and interpersonal skills necessary to solve business and/or social problems, such as mitigating the anthropic causes of climate change. For that, the TADEO Method is used in the design of teaching and learning experiences that use combinations of the drivers of digital transformation of education according to the context and specificities of students and teachers. According to Wolfe and Brandt (1998), a curriculum that focuses on solving real world problems can result in high curiosity, motivation and better academic performance. For Hussin (2018), Education 4.0 is an answer to the Fourth Industrial Revolution challenge, where human skills and digital technologies are aligned to enable new opportunities.

For experimentation with the TADEO Method, two teaching and learning experiences were planned and executed, but only one of them was reported in more detail in this work. Pedagogical drivers were used to format the systematic of the experience: agility, to perform tasks through sprints (iterations) timeboxing; Human-Centered Design (HCD), to guide the purpose and sequencing of sprints in alignment with the stages of discovery, ideation and implementation; and Problem-Based Learning (PBL), to encourage the use of student knowledge and skills needed to solve a welldefined problem. Technological drivers were used to enable remote, decentralized, 
collaborative and digital teaching and learning. Human drivers, related to the students 'soft and hard skills and the teachers' digital competence, were used and encouraged in the execution and orientation of the sprint tasks, respectively. Organizational drivers, related to the support of the educational institution regarding the experimentation of new teaching and learning approaches, were fundamental to improve the educational experience for an audience of digital natives. The digital transformation in education is achieved only with the holistic use of different types of drivers and not just digital technology by itself, in alignment with current studies such as the one presented by Himmetoglu et al. (2020).

The results obtained from feedback by students and educators indicate that the teaching and learning experiences guided by the TADEO Method achieved the expected purposes. The results obtained are also consistent with other studies (Puncreobutr, 2016; Cotet et al. 2017; Koul, \& Nayar, 2021; Silva et al. 2021) about Education 4.0 purposes. This work was concerned in: to exercise and equip students with technical, social and cognitive skills of communication, social and cultural awareness, creativity, empathy, critical and analytical thinking, problem solving, responsibility, teamwork, digital technology design, people management, technological resource management, time management and computational thinking, as well as interpersonal skills of collaboration, resilience and respect; strengthen the digital competence of teachers; raise environmental awareness and encourage more environmentally sustainable student behavior.

This study has some limitations about the teaching and learning experiences developed through the TADEO method, including: application only in the online teaching modality due to the prevention measures against COVID-19, thus lacking application in the modality presential; evaluation by a reduced number of students and teachers, requiring application and evaluation by more users in different educational environments; use of few combinations of drivers for digital transformation in education, the use being able to be extended to other combinations of drivers in different educational contexts and realities; the teachers involved had academic training in the area of technology, and it is important to investigate the use of the method by educators without proficiency in digital technologies; active monitoring by the author of the work, which may have influenced the autonomy of the teachers involved, and then strategies for training teachers for the autonomous application of the method could be tried, in line with the precept of Gal-Ezer and Stephenson (2010) that empowering the teachers to new ways of teaching is critical to the success of education.

The COVID-19 pandemic can be considered a turning point for the digital transformation towards Education 4.0. However, educators, students, and educational institutions are facing an accelerated transition to a new educational paradigm that strongly involves the use of diverse digital technologies, such as data analytics to generate information and knowledge from large volumes of data (Big Data) to personalize the teaching and learning process, but which also require innovative pedagogies, social, interpersonal and cognitive skills of students and teachers, as well as new organizational models. Given this scenario, the TADEO method can be a tool to contribute to this journey and help educators in the design of teaching and learning experiences based on the holistic use of human, technological and organizational drivers. 


\section{Acknowledgments}

This study was financed in part by the Coordenação de Aperfeiçoamento de Pessoal de Nível Superior - Brasil (CAPES) - Finance Code 001.

\section{References}

Ananiadou, K. \& Claro, M. (2009). 21st Century Skills and Competences for New Millennium Learners in OECD Countries. OECD Education Working Papers, No. 41, OECD Publishing, Paris, https://doi.org/10.1787/218525261154

Anderson, A. (2012). Climate change education for mitigation and adaptation. Journal of Education for Sustainable Development, 6(2), 191-206. https://doi.org/10.1177/0973408212475199

Ardoin, N.M., Bowers, A.W., \& Gaillard, E. (2020). Environmental education outcomes for conservation: A systematic review. Biological Conservation, 241, 108224. https://doi.org/10.1016/j.biocon.2019.108224

Assadourian, E. (2010). State of the World 2010: Transforming Cultures: From Consumerism to Sustainability (State of the World). WW Norton \& Company.

Azmi, A.N., Kamin, Y., Noordin, M.K., \& Nasir, A.N.M. (2018). Towards industrial revolution 4.0: employers' expectations on fresh engineering graduates. International Journal of Engineering \& Technology, 7(4.28), 267-272. https://www.sciencepubco.com/index.php/ijet/article/view/22593

Barbosa, R., \& Souza, R. (2021). Drivers and Indicators of Innovation to Educational Software. Informatics in Education, 20(1), 1-17. https://doi.org/10.15388/infedu.2021.01

Binkley, M., Erstad, O., Herman, J., Raizen, S., Ripley, M., Miller-Ricci, M., \& Rumble, M. (2012). Defining twenty-first century skills. In Assessment and teaching of 21st century skills (pp. 17-66). Springer, Dordrecht. https://doi.org/10.1007/978-94-007-2324-5_2

Bruegge, B., Reiss, M., \& Schiller, J. (2009). Agile principles in academic education: A case study. In 2009 Sixth International Conference on Information Technology: New Generations (pp. 1684-1686). IEEE. https://doi.org/10.1109/ITNG.2009.76

Burke, M., Hsiang, S.M., \& Miguel, E. (2015). Global non-linear effect of temperature on economic production. Nature, 527(7577), 235-239. https ://doi.org/10.1038/nature15725

Chakra, M.A., Bumann, S., Schenk, H., Oschlies, A., \& Traulsen, A. (2018). Immediate action is the best strategy when facing uncertain climate change. Nature communications, 9(1), 1-9. https : //doi.org/10.1038/s41467-018-04968-1

Cotet, G.B., Balgiu, B.A., \& Zaleschi, V.C. (2017). Assessment procedure for the soft skills requested by Industry 4.0. In MATEC web of conferences (Vol. 121, p. 07005). EDP Sciences.

https://doi .org/10.1051/matecconf/201712107005

Dudin, M.N., Frolova, E.E., Kucherenko, P.A., Samusenko, T.M., \& Voikova, N.A. (2016). Creating an Effective System of Education to Prepare Future Human Resources within the Context Provided by the Global Shift toward a" Green Economy". International journal of environmental and science education, 11(15), 8706-8717.https://files.eric.ed.gov/fulltext/EJ1118301.pdf

Ferguson, R., Coughlan, T., Egelandsdal, K., Gaved, M., Herodotou, C., Hillaire, G., ... \& Whitelock, D. (2019). Innovating Pedagogy 2019: Open University Innovation Report 7. Milton Keynes: Institute of Educational Technology, The Open University. https://iet.open.ac.uk/file/innovating-pedagogy-2019.pdf

Gal-Ezer, J., \& Stephenson, C. (2010). Computer science teacher preparation is critical. ACM Inroads, 1(1), 61-66. https://doi.org/10.1145/1721933.1721953

Glanemann, N., Willner, S.N., \& Levermann, A. (2020). Paris Climate Agreement passes the cost-benefit test. Nature communications, 11(1), 1-11. https://doi .org/10.1038/s41467-019-13961-1

Goh, P.S.C., \& Abdul-Wahab, N. (2020). Paradigms to drive higher education 4.0. International Journal of Learning, Teaching and Educational Research, 19(1), 159-171.

https://doi.org/10.26803/ijlter.19.1.9

Himmetoglu, B., Aydug, D., \& Bayrak, C. (2020). Education 4.0: Defining the teacher, the student, and the school manager aspects of the revolution. Turkish Online Journal of Distance Education, 21(Special IssueIODL), 12-28. https://doi.org/10.17718/tojde.770896 
Hmelo-Silver, C.E. (2004). Problem-based learning: What and how do students learn?. Educational psychology review, 16(3), 235-266. https ://doi.org/10.1023/B:EDPR.0000034022.16470.f3

Hong C., Ma W.W.K. (2020) Introduction: Education 4.0: Applied Degree Education and the Future of Work. In: Hong C., Ma W. (eds) Applied Degree Education and the Future of Work. Lecture Notes in Educational Technology. Springer, Singapore. https : //doi .org/10.1007/978-981-15-3142-2_1

Horby, P. (2018). Improving preparedness for the next flu pandemic. Nature microbiology, 3(8), 848-850. https://doi.org/10.1038/s41564-018-0206-7

Hotaling, L. (2021). Preparing the workforce for the new blue economy. In Preparing a Workforce for the New Blue Economy (pp. 387-405). Elsevier. https ://doi .org/10.1016/B978-0-12-821431-2.00015-9

Hussin, A.A. (2018). Education 4.0 made simple: Ideas for teaching. International Journal of Education and Literacy Studies, 6(3), 92-98. http://dx.doi.org/10.7575/aiac.ijels.v.6n.3p.92

IDEO. (2015). The field guide to human-centered design. https ://www. designkit.org/resources/1

Jurado-Navas, A., \& Munoz-Luna, R. (2017). Scrum Methodology in Higher Education: Innovation in Teaching, Learning and Assessment. International Journal of Higher Education, 6(6), 1-18. https://doi.org/10.5430/ijhe.v6n6p1

Koul, S., \& Nayar, B. (2021). The holistic learning educational ecosystem: A classroom 4.0 perspective. Higher Education Quarterly, 75(1), 98-112. https ://doi .org/10.1111/hequ .12271

Kukulska-Hulme, A., Beirne, E., Conole, G., Costello, E., Coughlan, T., Ferguson, R., ... \& Whitelock, D. (2020). Innovating Pedagogy 2020: Open University Innovation Report 8. Milton Keynes: Institute of Educational Technology, The Open University. https://iet.open.ac.uk/file/innovating-pedagogy-2020.pdf

Loiseau, E., Saikku, L., Antikainen, R., Droste, N., Hansjürgens, B., Pitkänen, K., ... \& Thomsen, M. (2016). Green economy and related concepts: An overview. Journal of cleaner production, 139, 361-371. https://doi.org/10.1016/j.jclepro.2016.08.024

Mahlow, C., \& Hediger, A. (2019). Digital Transformation in Higher Education-Buzzword or Opportunity?. eLearn Magazine, 2019(5), 13. https ://doi .org/10.1145/3331171

Manzanedo, R.D., \& Manning, P. (2020). COVID-19: Lessons for the climate change emergency. Science of the Total Environment, 742, 140563. https://doi.org/10.1016/j.scitotenv.2020.140563

Monroe, M., \& Krasny, M. (2015). Across the spectrum. North American Association for Environmental Education: Washington, DC, USA.

Norton, A., Shroff, S., \& Edwards, N. (2020). Digital Transformation: An Enterprise Architecture Perspective. Publish Nation Limited, UK.

Noviyanti, E., Rusdi, R., \& Ristanto, R.H. (2019). Guided discovery learning based on internet and self concept: enhancing student's critical thinking in biology. Indonesian Journal of Biology Education, 2(1), 7-14. https://doi.org/10.31002/ijobe.v2i1.1196

OECD. Organisation for Economic Co-operation and Development. (2019a). OECD Future of Education and Skills 2030: OECD Learning Compass 2030. OECD Publishing, Paris.

http://www . oecd.org/education/2030-project/teaching-and-learning/learning/learning-compass-2030/OECD_Learning_Compass_2030_Concept_Note_Series.pdf

OECD. Organisation for Economic Co-operation and Development. (2017). Getting Skills Right: Skills for Jobs Indicators, Getting Skills Right. OECD Publishing, Paris. 2017. https://doi.org/10.1787/9789264277878-en

OECD. Organisation for Economic Co-operation and Development. (2019b). Going Digital: Shaping Policies, Improving Lives. OECD Publishing, Paris. https : //doi .org/10.1787/9789264312012-en

OECD. Organisation for Economic Co-operation and Development. (2019c). OECD Skills Strategy 2019: Skills to Shape a Better Future, OECD Publishing, Paris. https : //doi . org/10.1787/9789264313835-en

OECD. Organisation for Economic Co-operation and Development. (2018a). Teaching for the future: Effective classroom practices to transform education. OECD, Publishing, Paris. https://doi.org/10.1787/9789264293243-en

OECD. Organisation for Economic Co-operation and Development. (2018b). The future of education and skills: Education 2030. OECD Education 2030. OECD Publishing, Paris. http: //www. oecd.org/education/2030-project/about/documents/E2030\%20Position $\% 20$ Paper\%20(05.04.2018).pdf

Oliveira, K.K.S., \& Souza, R.A. C. (2020a). Habilitadores da transformação digital em direção à Educação 4.0. RENOTE, 18(1). https://doi.org/10.22456/1679-1916.106012

Oliveira, K.K., \& de Souza, R. (2020b). Mudanças climáticas na educação: um levantamento das práticas, ferramentas e tecnologias digitais. In Anais do XI Workshop de Computação Aplicada à Gestão do Meio Ambiente e Recursos Naturais (pp. 151-160). SBC. DOI: https://doi.org/10.5753/wcama.2020.11029 
P21. Partnership for 21st Century Learning. (2019). Partnership for 21st Century Learning: Framework for 21st Century Learning Definitions. Battelle for Kids. http://static.battelleforkids.org/documents/p21/P21_Framework_DefinitionsBFK.pdf

Parsons, D., \& MacCallum, K. (2019). Agile education, Lean learning. In Agile and lean concepts for teaching and learning (pp. 3-23). Springer, Singapore. https ://doi .org/10.1007/978-981-13-2751-3_1

Peterson, A., Dumont, H., Lafuente, M., Law, N. (2018). Understanding innovative pedagogies: Key themes to analyse new approaches to teaching and learning, OECD Education Working Papers, No. 172, OECD Publishing, Paris. https://doi.org/10.1787/9f843a6e-en

Puncreobutr, V. (2016). Education 4.0: New challenge of learning. St. Theresa Journal of Humanities and Social Sciences, 2(2).

http://www.stic.ac.th/ojs/index.php/sjhs/article/view/Position\%20Paper3

Rao, M.S. (2018). Soft skills: Toward a sanctimonious discipline. On the Horizon. https://doi.org/10.1108/0TH-06-2017-0034

Rosenbloom, D., \& Markard, J. (2020). A COVID-19 recovery for climate. Science, 368, 447. https://science.sciencemag.org/content/368/6490/447.full

Schleicher, A. (2016). Teaching Excellence through Professional Learning and Policy Reform: Lessons from around the World, International Summit on the Teaching Profession, OECD Publishing, Paris. https://doi.org/10.1787/9789264252059-en

Schwaber, K. (2004). Agile project management with Scrum. Microsoft press.

Sharples, M., Roock, R., Ferguson, R., Gaved, M., Herodotou, C., Koh, E., .. \& Wong, L. H. (2016). Innovating pedagogy 2016: Open University innovation report 5. Milton Keynes: Institute of Educational Technology, The Open University. https ://iet.open.ac.uk/file/innovating_pedagogy_2016.pdf

Silva, D.E.D.S., Sousa, A.O., Oliveira, M.R., Sobrinho, M.C., Todt, E., \& Valentim, N.M.C. (2020). Education 4.0: Robotics Projects to Encourage 21st Century Skills. RENOTE, 18(2), 450-459. https://doi.org/10.22456/1679-1916.110285

Spinrad, R.W. (2021). The new blue economy. In Preparing a Workforce for the New Blue Economy (pp. 87-111). Elsevier. https ://doi.org/10.1016/B978-0-12-821431-2.00042-1

Trisos, C.H., Merow, C., \& Pigot, A.L. (2020). The projected timing of abrupt ecological disruption from climate change. Nature, 580(7804), 496-501. https ://doi .org/10.1038/s41586-020-2189-9

UN. United Nations. (2015). Transforming our World: The 2030 Agenda for Sustainable Development. https: //sustainabledevelopment.un.org/content/documents $/ 21252030 \% 20 \mathrm{Agenda} \% 20$ for $\% 20$ Sustainable\%20Development $\% 20$ web.pdf

UNEP. United Nations Environment Programme. (2011). Forests in a green economy: A synthesis. Sustainable Development. https://wedocs.unep.org/bitstream/handle/20.500.11822/7943/UNEPForestsGreenEco-basse_def_version_normale.pdf

UNEP. United Nations Environment Programme. (2012). Measuring progress towards an inclusive green economy. Nairobi: UNEP. https://wedocs . unep.org/bitstream/handle/20.500.11822/32438/MPGE.pdf

UNESCO. United Nations Educational, Scientific and Cultural Organization. (2013). Climate change in the classroom: UNESCO course for secondary teachers on climate change education for sustainable development. UNESCO Publishing, Paris. https : //unesdoc. unesco.org/ark:/48223/pf0000219752/PDF/219752eng.pdf.multi

UNESCO. United Nations Educational, Scientific and Cultural Organization. (2020) COVID-19 Educational Disruption and Response. https://pt.unesco.org/covid19/educationresponse [Accessed: 18.09.2020]

UNESCO. United Nations Educational, Scientific and Cultural Organization. (2016). Getting climate ready: a guide for schools on climate action and the whole-school approach. UNESCO Publishing, Paris. https: //unesdoc. unesco.org/ark: /48223/pf0000246740/PDF/246740eng.pdf . multi

UNESCO. United Nations Educational, Scientific and Cultural Organization. (2015). Not Just Hot Air: Putting Climate Change Education into Practice. UNESCO Publishing, Paris. https://unesdoc . unesco.org/ark:/48223/pf0000233083/PDF/233083eng.pdf.multi

UNESCO. United Nations Educational, Scientific and Cultural Organization. (1992). Report of the United Nations Conference on Environment and Development Rio de Janeiro, 3-14 June 1992. https://www . un.org/ga/search/view_doc. asp?symbol=A/CONF. 151/26/Rev. 1\%20 (Vol.\%20I) \&Lang=E

UNESCO. United Nations Educational, Scientific and Cultural Organization. (1972). Report on the United Nations Conference on the Human Environment. Stockholm. https://unesdoc. unesco.org/ark:/48223/pf0000001758/PDF/001758engb.pdf .multi 
UNESCO. United Nations Educational, Scientific and Cultural Organization. (2019). The ethical challenges of climate change. UNESCO Publishing, Paris.

https://unesdoc. unesco.org/ark:/48223/pf0000370032_eng/PDF/370032eng.pdf.multi

Vogelzang, J., Admiraal, W.F., \& Van Driel, J.H. (2020). A teacher perspective on Scrum methodology in secondary chemistry education. Chemistry Education Research and Practice, 21(1), 237-249.

https://doi.org/10.1039/c9rp00111e

WEF. World Economic Forum. (2016a). New Vision for Education: Fostering Social and Emotional Learning through Technology. Switzerland.

http://www3.weforum.org/docs/WEF_New_Vision_for_Education.pdf

WEF. World Economic Forum. (2017). Schools of the Future. Realizing Human Potential in the Fourth Industrial Revolution. An Agenda for Leaders to Shape the Future of Education, Gender and Work. Switzerland. http://www3.weforum.org/docs/WEF_EGW_Whitepaper.pdf

WEF. World Economic Forum. (2016b). The future of jobs: Employment, skills and workforce strategy for the fourth industrial revolution. In Global Challenge Insight Report, World Economic Forum. Cologny/ Geneva, Switzerland. http://www3. weforum.org/docs/WEF_Future_of_Jobs.pdf

WEF. World Economic Forum. (2020a). Schools of the Future. Defining New Models of Education for the Fourth Industrial Revolution. In Platform for Shaping the Future of the New Economy and Society. Cologny/Geneva, Switzerland.

http://www3. weforum.org/docs/WEF_Schools_of_the_Future_Report_2019.pdf

WEF. World Economic Forum. (2020b). The Future of Jobs Report 2020. Cologny/Geneva, Switzerland. http://www3. weforum.org/docs/WEF_Future_of_Jobs_2020.pdf

Wei, Y.M., Han, R., Wang, C., Yu,B., Liang, Q.M., Yuan, X.C., ... \& Yang, Z. (2020). Self-preservation strategy for approaching global warming targets in the post-Paris Agreement era. Nature communications, 11(1), 1-13. https://doi.org/10.1038/s41467-020-15453-z

Wolfe, P., \& Brandt, R. (1998). What Do We Know from Brain Research?. Educational Leadership, 56(3), $8-13$.

K.K. de S. Oliveira is a $\mathrm{PhD}$ student in Computer Science and Computational Mathematics at the University of São Paulo (USP). He received his MSc in Applied Informatics from the Federal Rural University of Pernambuco (UFRPE). Graduated in Systems Analysis and Development at Faculdade Vale do Salgado (FVS). His research interest area are Informatics in Education, Computational Thinking, Innovation in Education and Digital Transformation.

R.A.C. de Souza is an associate professor at the Department of Computer Science (DC) and permanent member at the Graduate Program of Applied Informatics (PPGIA) at Federal Rural University of Pernambuco (UFRPE) in Brazil. He received his MSc and $\mathrm{PhD}$ from the Federal University of Pernambuco (UFPE), Informatics Center (CIN) in Brazil. His research interest area are Innovation in Education, Digital Social Innovation, Digital Transformation, Digital Governance, Knowledge Management and Software Product Management. 
